\title{
PENAPISAN SENYAWA ANTIBAKTERI DAN TOKSISITAS DARI SPONS ASAL PERAIRAN PULAU BONERATE SULAWESI SELATAN
}

\author{
Theresia Dwi Suryaningrum*), Wizza Wirasty Pramadhany") dan Thamrin Wikanta*)
}

\begin{abstract}
ABSTRAK
Studi potensi farmakologi dari berbagai jenis spons dari perairan Pulau Bonerate, Sulawesi Selatan belum banyak dilakukan. Dalam penelitian ini dilakukan kajian aktivitas antibakteri dan uji toksisitas terhadap Artemia salina dari sampel yang diambil dari wilayah tersebut. Penelitian dilakukan melalui 2 tahap, yaitu: tahap 1, penapisan aktivitas antibakteri dari ekstrak kasar metanol dari 10 jenis spons yang diambil secara acak. Tahap 2, ekstraksi spons yang positif mengandung antibakteri dengan berbagai pelarut organik dan uji toksisitasnya. Uji aktivitas antibakteri dilakukan terhadap bakteri Bacillus subtilis, Escherichia coli, Pseudomonas aeruginosa, Salmonella typhymurium, Staphylococcus aureus, dan Streptococcus mutans. Uji toksisitas dilakukan menggunakan metode Brine Shrimp Lethality Test (BSLT). Hasil penelitian menunjukkan bahwa di antara 10 ekstrak sampel spons yang diuji hanya terdapat 1 sampel spons (TBSL-17) yang memiliki aktivitas antibakteri. Ekstraksi kasar dengan menggunakan pelarut heksana (non polar), etil asetat (semi polar), dan metanol (polar) menghasilkan rendemen masing-masing sebesar $0,95 \%, 0,01 \%$, dan 2,39\% (b/b). Hasil uji aktivitas antibakteri dari hasil ekstraksi sampel menunjukkan bahwa ekstrak metanol dan heksan memiliki aktivitas antibakteri uji tetapi aktivitasnya sangat lemah. Hasil uji toksisitas terhadap $A$. salina menunjukkan bahwa ekstrak metanol dan heksan bersifat sangat toksik dengan nilai LC $_{50}$ masing-masing sebesar 10,44 ppm dan 13,65 ppm. Hasil identifikasi terhadap sampel TBSL-17 menunjukkan bahwa spons tersebut adalah Aaptos sp. yang tergolong kelas Desmosponsgiae.
\end{abstract}

\section{ABSTRACT: Screening on the antibacterial and toxic coumpond of sponges from Bonerate Island Water, South Sulawesi. By: Theresia Dwi Suryaningrum, Wizza Wirasty Pramadhany and Thamrin Wikanta}

Study on pharmacological potency of various sponges collected from Bonerate Island waters, South Sulawesi is still limited. Research was carried out to reveal antibacterial activity and toxicity assay against Artemia salina. This research was conducted in 2 steps, i.e screening of antibacterial activity of the methanol crude extracts of 10 sponges collected on random basis, and extraction of the sponges that positively contain antibacterial substance using various organic solvents. Antibacterial activity assay was conducted against Bacillus subtilis, Escherichia coli, Pseudomonas aeruginosa, Salmonella typhymurium, Staphylococcus aureus, and Streptococcus mutans. In the meantime, the toxicity assay was carried out using Brine Shrimp Lethality Test (BSLT) method. The result showed that there was only 1 sample (TBSL-17) which has antibacterial activity. Extraction of the samples using hexane (nonpolar), ethyl acetate (semipolar), and methanol (polar) resulted yield of $0.95 \%, 0.01 \%$, and $2.39 \%(w / w)$, respectively. Results of antibacterial activity assay of each extract showed that methanol and hexane extract had antibacterial activity but the activities were very week. Result of toxicity against Artemia salina showed that the methanol and hexane extract belonged to category highly toxic with $L C_{50}$ value of $10.44 \mathrm{ppm}$ and 13.65 ppm respectively. Result of identification revealed that the TBSL-17 sample was derived from Aaptos sp which belong to Desmosponsgiae class.

KEYWORDS: $\quad$ sponges, toxicity, antibacterial

\section{PENDAHULUAN}

Spons merupakan karang lunak yang diketahui dapat menghasilkan senyawa bioaktif yang bermanfaat sebagai antibiotik, anti-jamur, anti-virus, anti-kanker, anti imflamasi, antioksidan yang selama ini terus dieksplorasi (Costafios, 1995, Proksch et al., 2003). Dalam tiga dekade belakangan ini 6.000 bioprospecting biota laut, antara lain 40 persen berasal dari spons dan 30 persen dari makroalgae telah berhasil diidentifikasi dan baru 11 bioprospecting spons yang sudah diuji klinis (Rachmat, 2004).

Peneliti pada Balai Besar Riset Pengolahan Produk dan Bioteknologi Kelautan dan Perikanan, DKP

Alumni Program Studi Teknologi Hasil Perikanan, Fakultas Perikanan dan IImu Perairan, Institut Pertanian Bogor. 
Senyawa bioaktif tersebut jika terbukti bermanfaat, kemudian dikembangkan guna memperoleh "lead compound" (senyawa tunggal), kemudian disintesis sebagai obat-obatan bagi kesehatan manusia, akan mempunyai nilai ekonomi yang sangat tinggi. Oleh karena itu dalam rangka memperoleh obat baru, spons menjadi filum yang paling banyak dieksplorasi karena memiliki banyak senyawa bioaktif dari berbagai tipe (Munro, 1999). Dari hasil penelitian berbagai spons di Binuangeuen diperoleh informasi bahwa spons jenis Axinella sp menunjukkan aktivitas terhadap sel lestari Leukeumia L-1210 dengan LC $_{50}$ sebesar 24,21 ppm. Demikian juga hasil pengujian aktivitas antibakteri menunjukkan bahwa ekstrak tersebut mempunyai spektrum yang luas dan aktif terhadap 6 jenis bakteri patogen yang diuji (Suryaningrum et al., 2005). Selanjutnya ekstrak spons Alcyoniidae yang diambil dari perairan Karimunjawa mempunyai aktivitas terhadap sel kanker HeLa dengan LC $_{50}$ sebesar 27,56 ppm, namun tidak memiliki aktivitas antibakteri (Nursid et al., 2005). Adapun hasil penelitian Rachmat et al. (2001) menunjukkan bahwa ekstrak kasar spons Aaptos sp memiliki bioaktivitas terhadap bakteri patogen Staphylococcus aereus, Bacillus subtilis dan Vibrio eltor. Dilaporkan oleh Nakamura et al. (1987) spons Aaptos aaptos mengandung senyawa alkaloid aaptamin yang memperlihatkan aktivitas terhadap alpha adrenoreceptor. Senyawa alkaloid tersebut adalah dimethyl-aaptamine dan dimethyl-(oxy) aaptamine yang memiliki aktivitas sitotoksik (antikanker), anti-virus dan antimikroba. Dilaporkan oleh Souza et al. (2007) dan Angelica et al. (2002) bahwa alkaloid 4-metylamine yang diisolasi dari Aaptos aaptos dapat menghambat inveksi virus herpes tipe-1. Spons Aaptos aaptos ini telah diteliti budidayanya dengan menggunakan metode transplantasi di terumbu karang di pulau Barranglompo Makasar (Rani \& Haris, 2005).

Pulau Bonerate terletak di sebelah selatan Makasar, termasuk dalam wilayah Taman Laut Nasional Taka Bonerate yang kaya dengan keanekaragaman biota laut. Perairan tersebut mempunyai hamparan terumbu karang atol yang luas dan masih terpelihara dengan baik dengan berbagai aneka ragam jenis spons. Kajian eksplorasi mengenai jenis-jenis spons dan potensi farmakologinya untuk memperoleh senyawa bioaktif dari perairan ini jarang dilakukan. Oleh karena itu untuk mengetahui potensi senyawa bioaktif terhadap berbagai jenis spons yang hidup di $P$. Bonerate dilakukan eksplorasi bahan aktifnya. Makalah ini melaporkan ekstraksi bahan aktif dari berbagai jenis spons, uji aktivitas anti bakteri serta uji toksisitasnya untuk mengetahui potensi farmakologinya.

\section{BAHAN DAN METODE}

\section{Bahan}

Bahan yang digunakan dalam penelitian ini adalah spons yang berasal dari Pulau Bonerate Sulawesi Selatan pada posisi $7^{\circ} 22,425^{\prime} \mathrm{LS}$ dan $121^{\circ} 2,5^{2} 5^{\prime}$ BT. Spons diambil dari kedalaman 1-40 m dengan cara scuba diving. Sampel kemudian dimasukkan ke dalam kantong plastik yang telah diberi metanol teknis. Dalam penelitian ini digunakan 10 jenis spons yang diambil secara acak dari hasil koleksi yang berjumlah 40 sampel. Bahan pembantu yang digunakan dalam penelitian ini adalah bahan pelarut organik metanol, etil asetat dan heksan serta bahan untuk uji toksisitas dan uji antibakteri.

\section{Metode Penelitian}

Penelitian ini dilakukan dengan menggunakan metode eksploratif deskriptif untuk mengetahui potensi komponen antibakteri pada 10 jenis ekstrak spons yang dilakukan dengan 2 tahap. Tahap pertama adalah penapisan komponen antibakteri dari spons serta uji antibakteri dan toksisitasnya. Tahap ke 2 adalah ekstraksi dengan berbagai pelarut organik terhadap spons yang positif mengandung senyawa antibakteri serta uji antibakteri dan toksisitasnya.

\section{Penapisan Komponen Antibakteri dari Spons}

Sebanyak 10 jenis spons ditimbang beratnya masing-masing $200 \mathrm{~g}$, kemudian dipotong-potong dan dimasukkan dalam erlenmeyer. Sampel kemudian diberi pelarut metanol $70 \%$ sampai terendam $(300 \mathrm{ml})$ kemudian dimaserasi selama 24 jam, disaring menggunakan kertas saring Whatman no. 4 untuk memisahkan filtrat dan residunya. Filtrat ditampung dan residu dimaserasi kembali dengan cara dan waktu yang sama. Proses maserasi dilakukan hingga 3 kali, seluruh volume filtrat dikumpulkan dan dievaporasi pada suhu $25^{\circ} \mathrm{C}$ dan tekanan rendah (50 mbar) untuk menguapkan pelarut sehingga diperoleh ekstrak yang pekat. Ekstrak pekat kemudian dikeringkan dengan menggunakan pengering beku sehingga diperoleh ekstrak kasar. Ekstrak kemudian diuji toksisitasnya dengan metode Brine Shrimp Lethality Test (BSLT) dan aktivitas antibakterinya diuji dengan menggunakan metode difusi agar.

\section{a. Uji toksisitas menggunakan metoda Brine Shrimp Lethality Test (BSLT)}

Uji toksisitas dengan metode BSLT menggunakan Artemia salina dilakukan menurut metode Meyer et al. (1982), McLaughlin \& Rogers (1998) dan Carballo 
et al. (2002). Dalam uji ini digunakan larva Artemia salina sebagai hewan uji. Telur $A$. salina ditetaskan di dalam air laut buatan dengan salinitas $38 \mathrm{ppt}$ (38 g garam dapur dalam $1000 \mathrm{ml}$ air biasa) di bawah lampu TL 40 watt. Setelah 48 jam telur menetas menjadi nauplii instar III/IV dan siap digunakan sebagai hewan uji. Sebanyak 30 larva $A$. salina dimasukkan ke dalam vial yang telah berisi larutan ekstrak sampel dengan konsentrasi berturut turut 10,100, dan 1.000 ppm dan ditambahkan air laut buatan sampai volume mencapai $5 \mathrm{ml}$. Air laut buatan tanpa pemberian ekstrak (0 ppm) digunakan sebagai kontrol. Semua vial diinkubasi pada suhu kamar selama 24 jam di bawah penerangan lampu TL 40 watt. Pengamatan dilakukan setelah 24 jam dengan melihat jumlah Artemia salina yang mati pada tiap konsentrasi ekstrak sampel. Setiap percobaan diulang 3 kali. Penentuan harga $\mathrm{LC}_{50}$ dalam $\mu \mathrm{g} / \mathrm{ml}$ atau $\mathrm{ppm}$ dilakukan menggunakan analisis probit berdasarkan konsentrasi ekstrak dan jumlah artemia yang mati, $\mathrm{LC}_{50}$ dihitung dengan cara meregresikan log konsentrasi dengan mortalitas probit yang didapat.

\section{b. Uji aktivitas antibakteri}

Uji antibakteri dilakukan dengan menggunakan metode Harapini dan Pratiwi (2004). Bakteri uji yang digunakan adalah bakteri patogen baik yang bersifat gram negatif maupun positif yaitu: Escherichia coli, Pseudomonas aeruginosa, Salmonella typhymurium, Bacillus subtillis, Staphylococcus aureus yang diperoleh dari Pusat Antar Universitas Bioteknologi Institut Pertanian Bogor (IPB) dan Steptococcus mutans yang diperoleh dari Departemen Teknologi Hasil Perairan IPB. Sebanyak $20 \mu \mathrm{L}$ isolat masingmasing bakteri uji dimasukkan ke dalam media Muller Hinton II Agar, kemudian dihomogenkan dan dimasukkan ke dalam cawan petri hingga memadat. Kertas cakram yang digunakan untuk uji ditetesi dengan $20 \mu \mathrm{L}$ larutan ekstrak dengan konsentrasi 100 , 1.000 dan 10.000 ppm, kemudian dibiarkan beberapa saat sampai kering. Kertas cakram yang sudah kering diletakkan dalam cawan petri yang sudah berisi bakteri dan diinkubasi pada suhu $37^{\circ} \mathrm{C}$ selama 24 jam. Aktivitas antibakteri dilihat dengan mengukur diameter zona hambat pertumbuhan (zona bening) di sekitar kertas cakram. Antibakteri dikatakan positif jika terbentuk zona bening di sekeliling kertas cakram.

\section{c. Identifikasi spon terpilih}

Identifikasi spon terpilih dilakukan terhadap sampel spon yang positif mempunyai aktivitas toksikologi dan antibakteri yang tinggi. Identifikasi dilakukan di Pusat Penelitian Oseanografi LIPI Jakarta.

\section{Ekstraksi Spons dengan Berbagai Pelarut Organik}

Ekstraksi terhadap spons yang mempunyai aktivitas antibakeri positif dengan menggunakan pelarut yang berbeda dilakukan agar semua komponen bioaktif dapat terekstrak sesuai dengan tingkat kepolarannya. Di samping itu juga untuk mengetahui aktivitas antibakteri dan toksikologi masing-masing ekstrak. Proses ekstraksi dilakukan secara bertahap dengan menggunakan 3 pelarut yaitu heksan (non polar), etil asetat (semi polar) dan metanol (polar), masing-masing sebanyak $300 \mathrm{ml}$ dengan cara maserasi secara berturut-turut sehingga diperoleh 3 ekstrak yaitu: ekstrak nonpolar (n-heksan), ekstrak semi polar (etil asetat) dan ekstrak polar (metanol-air). Ketiga ekstrak tersebut kemudian dievaporasi, hingga seluruh pelarut organik menguap. Kemudian ekstrak dikeringkan pada suhu rendah dengan menggunakan pengering beku sehingga diperoleh ekstrak berbentuk bubuk. Diagram alir proses ekstraksi disajikan pada Gambar 1. Ekstrak yang diperoleh kemudian diuji aktivitasnya terhadap antibakteri dan toksisitasnya dengan menggunakan metode yang dilaporkan sebelumnya (Harapini \& Pratiwi, 2004).

\section{HASIL DAN BAHASAN}

\section{Penapisan Senyawa Bioaktif dari Ekstrak Kasar Berbagai Jenis Spons}

\section{a. Rendemen ekstrak kasar berbagai jenis spons}

Hasil penapisan komponen senyawa bioaktif dari 10 jenis spons dengan metanol, menghasilkan rendemen yang berbeda-beda berkisar antara 0,18$1,75 \%$ seperti terlihat pada Gambar 2. Hasil penelitian menunjukkan, umumnya rendemen senyawa bioaktif yang terkandung dalam spons sangat kecil. Dalam penelitian ini rendemen tertinggi diperoleh dari spons dengan kode TBSL 17. Hal ini diduga bahwa spons dengan kode TBSL 17 memiliki senyawa bioaktif yang bersifat polar lebih banyak dibandingkan dengan sembilan sampel lainnya. Hasil pengamatan secara morfologi menunjukkan, bahwa spons yang teksturnya padat, lunak halus dan lentur seperti karet mempunyai rendemen senyawa bioaktif yang relatif lebih besar dibandingkan dengan spons yang teksturnya rapuh, kaku, kasar dan mudah patah. Umumnya senyawa bioaktif dari spons yang dihasilkan sangat kecil, namun demikian rendemen yang sangat kecil tersebut akan mempunyai nilai ekonomi tinggi, jika senyawa yang dihasilkan potensial sebagai bahan obat dan 


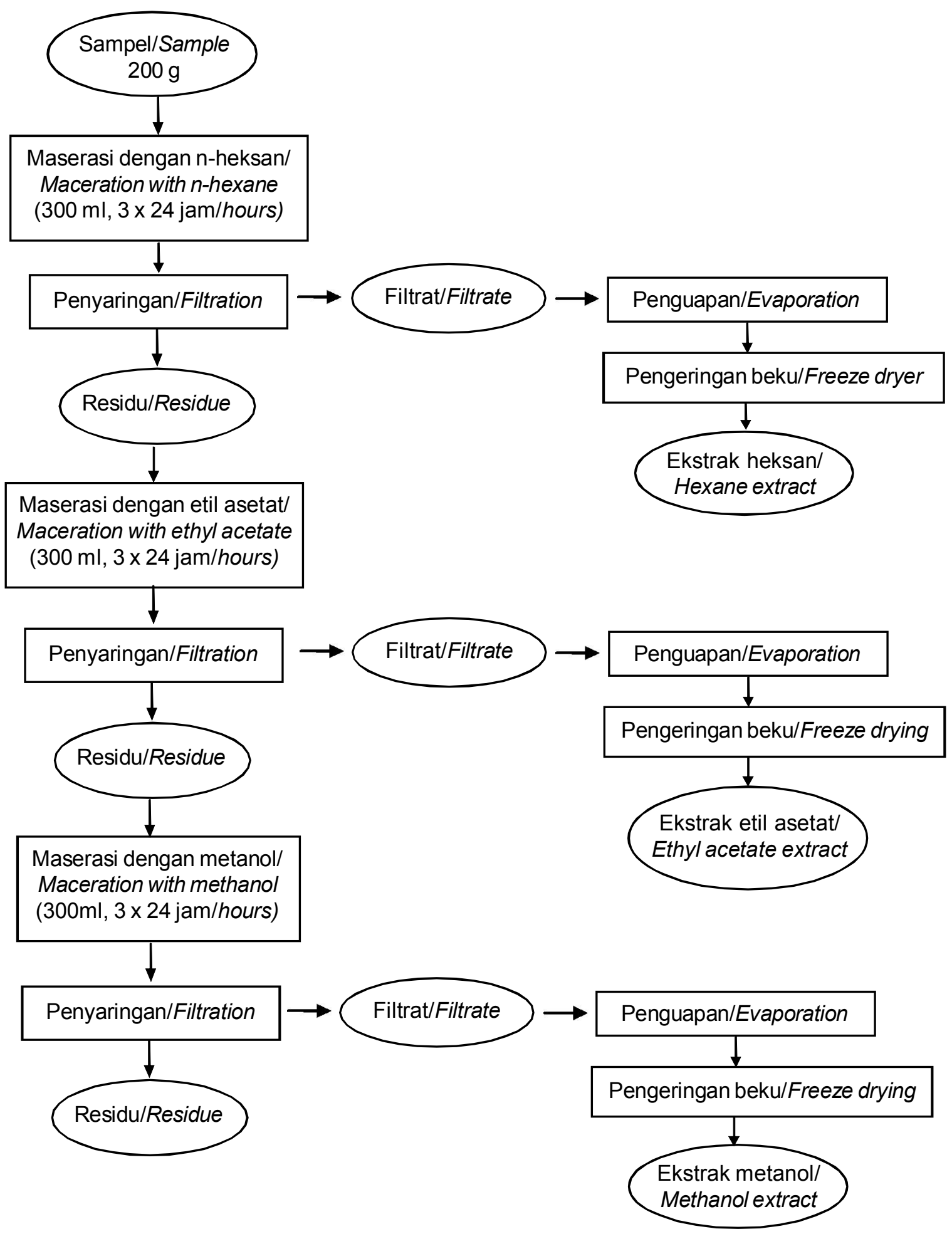

Gambar 1. Diagram ekstraksi spons dengan heksan, etil asetat dan metanol.

Figure 1. Flow chart of sponges extraction with hexane, ethyl acetate and methanol. 


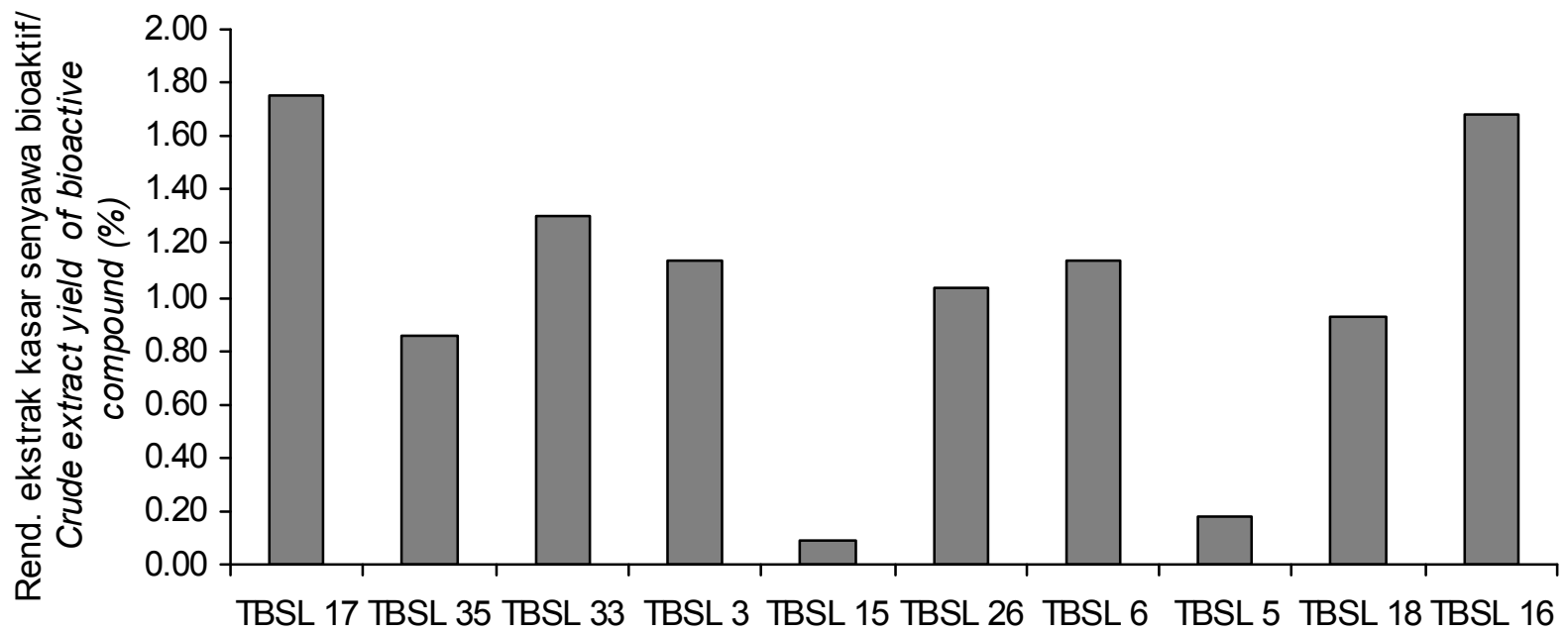

Sampel spons/Sponge samples

Gambar 2. Rendemen hasil ekstraksi senyawa bioaktif spons dari P. Bonerate.

Figure 2. Yield of extract of bioactive compound from P. Bonerate sponges.

nantinya dapat dikembangkan dengan mensintesisnya.

\subsection{Uji toksisitas berbagai ekstrak spons terhadap Artemia salina}

Hasil uji toksisitas terhadap 10 jenis spons dengan menggunakan metode BSLT menunjukkan bahwa 7 jenis spons yang diuji memiliki aktivitas toksikologi dengan kategori sangat toksik dengan nilai $\mathrm{LC}_{50}$ di bawah 30 ppm. Sedangkan ekstrak dengan kode sampel TBSL 15 mempunyai nilai LC $_{50}$ sebesar 69,68 ppm yang masih tergolong toksik dan ekstrak sampel TBSL 3 dengan $L_{50}$ sebesar 971,18 ppm tergolong toksisitas rendah (Meyer et al., 1982). Hanya satu sampel yang tergolong tidak toksik dengan $\mathrm{LC}_{50}$ di atas 1000 seperti terlihat pada Tabel 1.

Tabel 1. Hasil uji toksisitas ekstrak spons dari P. Bonerate Sulawesi Selatan

Table 1. Result of toxicity test of sponges extract from P. Bonerate South Sulawesi

\begin{tabular}{cccc}
\hline No & $\begin{array}{c}\text { Kode Sampel/ } \\
\text { Sample code }\end{array}$ & LC $_{50}(\mathbf{p p m})$ & Keterangan/Note \\
\hline 1 & TBSL 17 & 0.48 & Sangat toksik/High toxicity \\
2 & TBSL 35 & 4.71 & Sangat toksik/High toxicity \\
3 & TBSL 33 & 6596.29 & Tidak toksik/Non toxic \\
4 & TBSL 3 & 971.18 & Toksiksitas rendah/Low toxicity \\
5 & TBSL 15 & 69.68 & Toksik/Toxic \\
6 & TBSL 26 & 11.41 & Sangat toksik/High toxicity \\
7 & TBSL 6 & 7.01 & Sangat toksik/High toxicity \\
8 & TBSL 5 & 4.64 & Sangat toksik/High toxicity \\
9 & TBSL 18 & 1.52 & Sangat toksik/High toxicity \\
10 & TBSL 16 & 11.55 & Sangat toksik/High toxicity \\
\hline
\end{tabular}


Pada tabel tersebut semakin kecil nilai $\mathrm{LC}_{50}$ semakin besar toksisitasnya. Menurut Meyer et al. (1982) senyawa dikatakan sangat toksik bila mempunyai nilai $L_{50}$ lebih kecil atau sama dengan $30 \mathrm{ppm}$, sedangkan bila nilai $\mathrm{LC}_{50}$ antara $30-100 \mathrm{ppm}$ termasuk toksik, dan antara 100-1000 ppm termasuk toksisitas rendah. Menurut Alam (2002) beberapa senyawa bioaktif menunjukkan korelasi dengan sitotoksin terhadap sel kanker jika $\mathrm{LC}_{50}<30 \mathrm{ppm}$. Lebih lanjut McLaughlin \& Rogers (1998) mengatakan bahwa nilai $\mathrm{ED}_{50}$ (dosis efektif suatu zat yang mampu membunuh $50 \%$ dari populasi sel uji) untuk sitotoksin umumnya sepersepuluh dari nilai $\mathrm{LC}_{50}$ yang diperoleh dari BSLT. Dari hasil penelitian ini dapat disimpulkan bahwa sebagian besar spons yang diuji (7 sampel) memiliki potensi untuk diteliti lebih lanjut aktivitasnya sebagai antikanker. Spons dengan Kode TBSL 17 memiliki nilai $L_{50}$ yang paling tinggi yaitu $0,48 \mathrm{ppm}$. Nilai ini termasuk dalam kategori toksisitas sangat tinggi (0,1-1 ppm ) (Kamrin, 1997). Tingginya tingkat toksisitas pada sebagian besar spons ini dapat dikaitkan dengan lingkungan ekologis dimana spons hidup. Spons ini bertubuh lunak, tumbuh menempel pada suatu karang, bersifat sesil (menetap), dan tanpa perlindungan (cangkang). Untuk mempertahankan dirinya dari predator seperti ikan dan hewan lainnya spons tersebut membentuk senyawa kimia berupa metabolit sekunder. Sesuai dengan fungsinya untuk mempertahankan diri, senyawa metabolit sekunder tersebut bersifat toksik dan berbau, sehingga ikan enggan untuk memangsanya. Senyawa metabolit sekunder dari spons telah banyak diteliti dalam rangka pencarian obat untuk kanker serta pencarian antibiotik baru untuk menggantikan antibiotik yang ada di pasaran, yang sudah tidak mampu mematikan mikroorganisme akibat meningkatnya resistensi.

\section{b. Aktivitas antibakteri ekstrak kasar hasil penapisan}

Aktivitas antibakteri ekstrak kasar berbagai jenis spons ditunjukkan dengan adanya zona hambatan (bening) di sekililing kertas cakram yang mengandung larutan zat yang diuji. Hasil uji aktivitas antibakteri terhadap 10 jenis spons menunjukkan hanya 1 (satu) jenis spons dengan kode TBSL 17 yang positif mengandung senyawa antibakteri baik gram positif maupun negatif, sedangkan 9 jenis ekstrak spons lainnya tidak menunjukkan adanya zona hambat. Ekstrak TBSL 17 mampu menghambat pertumbuhan semua bakteri patogen yang diuji yaitu Escherichia coli, Bacillus subtilis, Salmonella typhymurium, Streptococcus aureus, Pseudomonas aeruginosa dan Streptococcus mutans namun aktivitas antibakterinya tergolong lemah. Menurut Rachdiati (2003), aktivitas anti bakteri digolongkan lemah apabila zona hambatan yang terbentuk di sekitar kertas cakram kurang dari $5 \mathrm{~mm}$. Bila dibandingkan dengan aktivitas kloramfenikol yang menunjukkan zona hambatan yang cukup besar dengan kisaran 11-17 mm pada seluruh bakteri uji, maka senyawa aktif ekstrak spons TBSL 17 tersebut sangat lemah karena hanya mampu menghambat dengan zona hambatan $1 \mathrm{~mm}$.

\section{c. Identifikasi spons TBSL 17}

Untuk mengetahui spesies sampel TBSL 17 dilakukan identifikasi dengan mengamati morfologi sampel yang meliputi bentuk luar, ukuran, warna, tekstur, permukaan, konsistensi, oskula, dan lokasi tempat asal sampel sehingga diketahui genusnya. Berdasarkan hasil identifikasi yang dilakukan oleh Pusat Penelitian Oseanografi LIPI dengan menggunakan kunci determinasi berdasarkan ciri morfologi spons TBSL 17 tergolong dalam Filum : Porifera, Kelas Desmosponsgia, Ordo: Hadromerida, Famili : Subteridae, Genus : Aaptos dan Species: Aaptos sp termasuk dalam kelas Desmosponsgiae karena memiliki bentuk pertumbuhan yang masif dan jaringan yang relatif keras dibandingkan dengan spons lainnya. Di Indonesia penyebarannya terbatas pada perairan Indonesia Timur, khususnya Sulawesi dan Nusa Tenggara Barat (Rachmat et al., 2001). Spons Aaptos sp memiliki morfologi bagian luar berwarna kuning kecoklatan, bagian dalam berwarna orange, dengan tekstur padat, kuat dan dapat ditekan seperti daging. Ukuran tubuh panjang $20 \mathrm{~cm}$ lebar $5 \mathrm{~cm}$, berat $460 \mathrm{~g}$ hidup terekpos melekat pada celah vertikal karang pada kedalaman 20-30 m. Permukaan tubuh berisi butiran-butiran yang kecil, berkutil atau halus. Spons ini merupakan koloni spons pantai yang hidup agresif dan dasar karang yang ditempelinya cepat rusak. Hidup pada suhu $22-26^{\circ} \mathrm{C}$, makanan spons ini adalah plankton yang tersebar di Indopasifik, Malaysia (Erhardt, 1995)

\section{Ekstraksi Spons TBSL 17 dengan Berbagai Pelarut Organik}

\section{a. Rendemen hasil ekstraksi}

Hasil ekstraksi sampel TBSL 17 dengan menggunakan berbagai pelarut organik metanol (polar), heksan (non polar) dan etil asetat (semi polar) menghasilkan tiga ekstrak yang berbeda berdasarkan jenis pelarut yang digunakan. Untuk ekstrak heksan dihasilkan produk yang berwarna coklat, ekstrak etil asetat berwarna kuning cerah dan ekstrak metanol berwarna hijau tua. Demikian juga rendemen yang dihasilkan, bervariasi seperti terlihat pada Gambar 3. Dari Gambar 3 terlihat bahwa ekstraksi dengan 


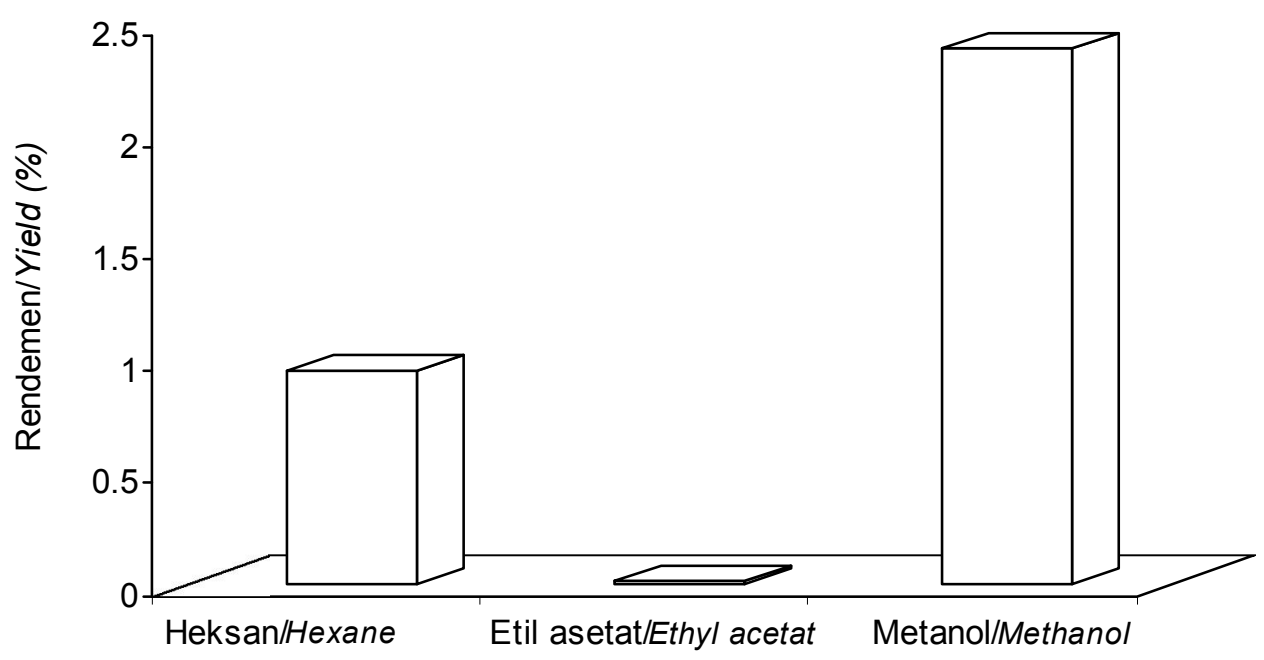

Figure 3. Yield of fractination from TBSL 17.

menggunakan pelarut metanol menghasilkan rendemen yang paling tinggi dibandingkan dengan ekstraksi menggunakan pelarut lainnya. Hal ini menunjukkan bahwa senyawa aktif yang terkandung dalam sampel TBSL 17 merupakan senyawa yang sebagian besar tersusun dari gugus polar, yang larut dalam pelarut polar, dibandingkan dengan senyawa yang bersifat non polar dan semi polar. Hasil penelitian ini sesuai dengan penelitian Murniasih (2003) yang menyatakan bahwa sebagian besar komponen aktif pada spons berupa senyawa polar.

\section{b. Uji toksisitas hasil ekstraksi}

Hasil pengujian toksisitas dengan menggunakan metode BSLT (McLaughlin \& Rogers, 1998) dapat dilihat pada Gambar 4. Ekstrak TBSL 17 dengan metanol dan heksan mampu mematikan 50\% larva uji pada konsentrasi yang sangat rendah yaitu $10 \mathrm{ppm}$, setelah 24 jam inkubasi. Sedangkan ekstrak etil asetat baru dapat mematikan $50 \%$ larva uji pada konsentrasi 1000 ppm. Sedangkan pada kontrol menunjukkan bahwa semua larva yang diuji tidak

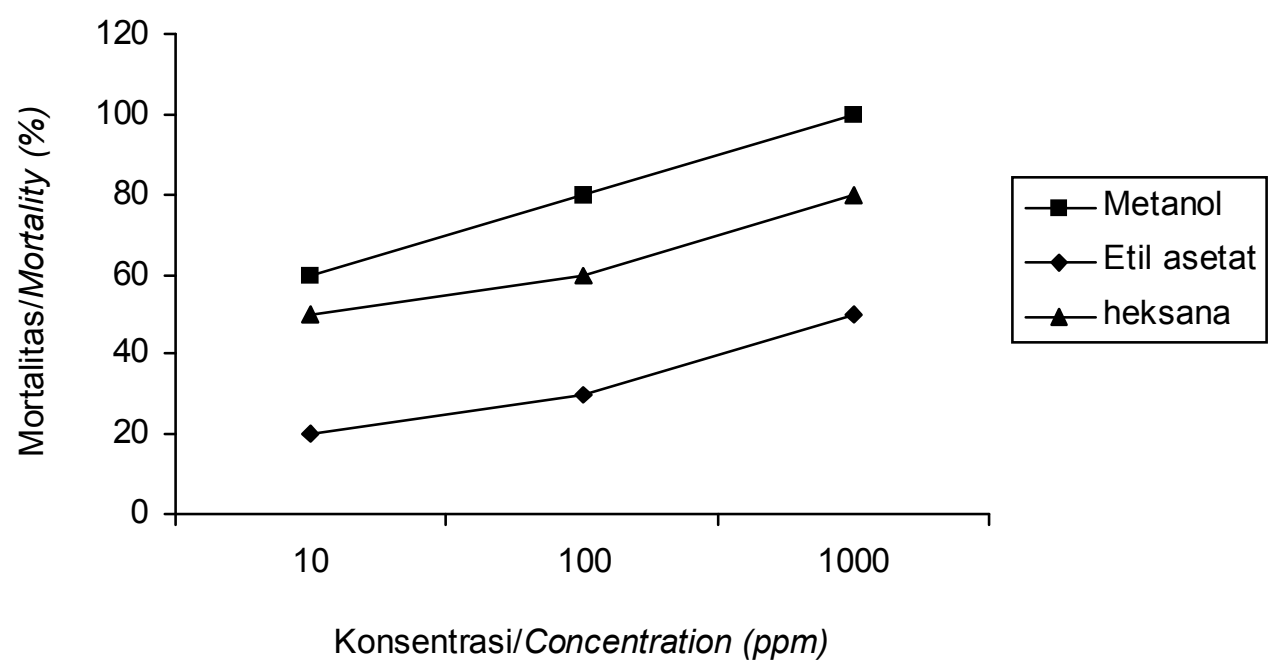

Gambar 4. Toksisitas sampel TBSL 17 terhadap Artemia salina yang diuji dengan ekstrak heksan, etil asetat dan metanol

Figure 4. Toxicicity of TBSL 17 hexane, ethyl acetate and methanol extract against Artemia salina. 
mengalami kematian. Jumlah larva yang mati pada kontrol biasanya digunakan sebagai faktor koreksi dalam menghitung persentase larva yang mati sebagai akibat penambahan ekstrak. Berdasarkan data mortalitas yang diperoleh, maka dapat ditentukan mortalitas probitnya. Regresi antara log konsentrasi dengan mortalitas probit yang didapat ditentukan nilai $\mathrm{LC}_{50}$ nya yang ditunjukkan pada Tabel 2 . (non polar) yang dilakukan terhadap 6 jenis bakteri patogen yang tergolong dalam gram positif yaitu $\mathrm{Ba}-$ cillus subtilis, Staphyloccocus aureus dan Streptococcus mutans dan yang tergolog dalam gram negatif yaitu Escherichia coli, Pseudomonas aeruginosa, Salmonella typhymurium, diperoleh bahwa tidak semua ekstrak yang diuji dapat menghambat pertumbuhan bakteri uji. Hanya ekstrak metanol dan

Tabel 2. Hasil uji toksisitas ekstrak spons Aaptos sp. terhadap Artemia salina

Table 2. Result of toxicity extracts of Aaptos sp. against Artemia salina

\begin{tabular}{crcl}
\hline No & Fraksi/ Fraction & LC $50(\mathbf{p p m})$ & \multicolumn{1}{c}{ Keterangan /Note } \\
\hline 1 & n-Heksan/n-Hexane & 10.44 & Sangat toksik/High toxicity \\
2 & Etil asetat/Ethyl acetate & 1200.33 & Tidak toksik/Non toxic \\
3 & Metanol/Methanol & 13.65 & Sangat toksik/High toxicity \\
\hline
\end{tabular}

Berdasarkan nilai $\mathrm{LC}_{50}$ yang didapat dari ketiga ekstrak, diketahui bahwa ekstrak metanol dan ekstrak heksan bersifat sangat toksik dengan nilai $\mathrm{LC}_{50}$ di bawah 30 ppm yaitu sebesar 10,44 ppm dan 13,65 ppm. Nilai ini menunjukkan bahwa ektrak metanol sebesar 10,44 ppm sudah dapat menyebabkan mortalitas sebesar $50 \%$. Hal ini menunjukkan adanya bahan metabolit aktif yang bersifat toksik apabila spons TBSL 17 tersebut diekstrak dengan menggunakan metanol dan heksan.

Sedangkan jika spons TBSL 17 diekstrak dengan menggunakan etil asetat, ekstrak tersebut tidak bersifat toksik karena nilai $\mathrm{LC}_{50}$ nya di atas $1.000 \mathrm{ppm}$, yaitu sebesar 1.200,33 ppm. Metabolit aktif yang bersifat toksik tersebut merupakan indikasi positif bahwa ekstrak tersebut bersifat sitotoksik terhadap sel kanker. Isolasi dan karakterisasi senyawa bioaktif dari spons laut Aaptos yang diambil dari laut Okinawa juga pernah dilakukan oleh Nakamura et al. (1987). Hasilnya dilaporkan bahwa Aaptos aaptos mengandung 2 senyawa alkaloid aaptamine yaitu dimethyl aaptamine dan dimethyl oxy aaptamine yang bersifat sitotoksik dan anti bakteri. Selanjutnya hasil penelitian Souza et al. (2007) menunjukkan bahwa alkaloid 4-metilamin yang diisolasi dari Aaptos aaptos dapat menghambat virus herpes simplek type 1 dengan $\mathrm{EC}_{50}$ sebesar 2,4 $\mu \mathrm{M}$. Setiawan (2004) juga melaporkan bahwa ekstrak spons Aaptos $s p$ mengandung 9-dimetoksiaaptamin yang aktif terhadap sel kanker kolon.

\section{c. Uji antibakteri hasil ekstraksi}

Uji aktivitas antibakteri terhadap ketiga ekstrak metanol (polar), etil asetat (semi polar) dan heksan heksan pada konsentrasi $10^{4} \mathrm{ppm}$ yang dapat menghambat keenam bakteri uji yang ditandai dengan terbentuknya zona bening di sekitar kertas cakram pada media agar. Zona hambatan yang terbentuk di sekitar kertas cakram, diameternya sangat kecil, hanya $1-3 \mathrm{~mm}$ atau kurang dari $5 \mathrm{~mm}$, yang menurut Harapini \& Pratiwi (2004) aktivitas antibakterinya tergolong sangat lemah.

\section{KESIMPULAN}

Berdasarkan hasil penapisan komponen antibakteri dan toksisitas terhadap 10 jenis spons yang diperoleh dari Pulau Bonerate hanya diperoleh 8 sampel yang bersifat toksik dengan LC $_{50} 24$ jam berkisar antara 0,48-69,68 ppm dan hanya 1 sampel (TBSL 17) yang mengandung senyawa antibakteri. TBSL 17 ternyata tergolong dalam spesies Aaptos sp. Ekstraksi spons TBSL 17 dengan menggunakan berbagai pelarut metanol (polar), etil asetat (semi polar) dan heksan (non polar) menghasilkan ekstrak polar (metanol) yang paling banyak, kemudian ekstrak non polar (heksan) dan yang paling kecil adalah ekstrak etil asetat (semi polar). Ekstrak metanol dan heksan mempunyai aktivitas antibakteri terhadap bakteri Gram positif dan Gram negatif, tetapi aktivitasnya sangat lemah. Ekstrak etil asetat bahkan tidak mempunyai aktivitas antibakteri. Hasil uji toksisitas dengan menggunakan metode BSLT menunjukkan bahwa ekstrak metanol dan heksan bersifat sangat toksik, sedangkan ekstrak etil asetat bersifat tidak toksik.

\section{SARAN}

Mengingat bahwa hasil uji toksisitas terhadap ekstrak metanol dan heksan dari ekstrak Aaptos sp bersifat sangat toksik, maka spons tersebut 
mempunyai potensi untuk diteliti lebih Ianjut aktivitasnya sebagai antikanker.

\section{DAFTAR PUSTAKA}

Alam, G. 2002. Brine Shrimp Lethality Test (BSLT) sebagai bioassay dalam isolasi senyawa bioaktif dari bahan alam. Majalah Farmasi dan Farmakologi, 6(2): 432-435.

Angelica F.C.B., Souza, TM., Frurulhettia, IC. and de A Epifanio, R. 2002. Anti HSV-1 Alkaloids from a feeding deterrent marine sponge of the genus Aaptos. Heterocycles. 57(7): 1265-1272.

Castafios. M. 1995. Drug from the Sea. Aqua Farm News. 13(5): 24.

Carballo, JL., Hernandez, IZL., Perez P., and Garcia, GMD. 2002. A comparison between two brine shrimp assay to detect in vitro cytotoxicity in marine natural product methodology article. J. BMC Biotechnology. 2: 15.

Erhardt, H. 1995. Invertebrata. Meerwasser Atlas, Band 2 Wirbellose Tiere. Mergus. 95 pp.

Harapini, M. dan Pratiwi. 2004. Pengujian antibakteri dan antioksidan ekstrak kulit batang siuri. Majalah Farmasi Indonesia. 15(3):151-157.

Kamrin, MA. 1997. Pesticide Profile: Toxicity, Enviromental, Impact and Fate. Boca Raton: Lewis Publisher.

McLaughlin, J.L and Rogers, L.L. 1998. The use of biological assay to evaluate botanicals. Drug Information Journal. 32: 513-524.

Meyer, B.N., Ferrigni, N.R., Putman, J.E., Jacobsen, L.B., Nichols, D.E., and McLauglin, J.L. 1982. Brine shrimp: a convenient general bioassay for active plant constituents. Planta Med. 45: 35-34.

Munro, M.H.G. 1999. The discovery and development of marine compounds with pharmaceutical potential. Journal of Biotechnology. 70: 15-25.

Murniasih, T. 2003. Metabolit sekunder dari spons sebagai bahan obat-obatan. Oseana. 28(3): 27-33.
Nakamura, H., Kobayashi, J., Ohizumi, Y. and Hirata, Y. 1987. Aaptamines. Novel benzo [de] [1,6] naphthyridines from the okinawan marine sponge Aaptos aaptos. J. Chem Soc. Perkin Trans 1. p. 173-176.

Nursid, M., Munifah, I. dan Januar. H.I. 2005. Skrining senyawa bioaktif ekstrak metanol dari karang lunak Alcyoniidae. J. Penel. Perikanan Indonesia. 2(4): 33-39.

Proksch. R.E., Edrada, RA. and Ebel, R. 2003. Drugs from the sea-opportunities and obstacles. Marine Drugs. 1: 5-17.

Rachdiati, H. 2003. Menanam rumput laut memanen antibiotik: http//www. kehati.or.id/news/view. 3 pp.

Rachmat, R. 2004. Kegiatan Bioteknologi Kelautan pada Lembaga IImu Pengetahuan Indonesia. Makalah pada forum Bioteknologi Kelautan dan Perikanan. Pusat Penelitian Oceanografi LIPI.

Rachmat, R., Kobayashi, M., dan Rasyid, A. 2001. Substansi anti kanker dari spons Aaptos sp asal Baranglompo Kep Spermonde Indonesia. Prosiding seminar laut Nasional III : 29-31 Mei 2001 Jakarta : p. 23-27.

Rachmat, R. Murniasih, dan Untari, F. 2001. Substansi bioaktif dari spons sebagai "Lead Coumpound" antimikroba. Laporan Penel. Pusat Penelitian Oceanografi LIPI. 4 pp.

Rani, C. dan Haris, A. 2005. Metode transplatasi spon laut Aaptos aaptos dengan teknik fragmentasi di terumbu karang Pulau Barranglompo, Makasar. Http/ /www.unhas.acid/-piu/karyailmiah/berkas diakses tanggal 9 April 2007. 12 pp.

Suryaningrum, T.D., Wikanta, T., dan Sugiyono. 2005. Skrining bioaktivitas ekstrak karang lunak Axinella $s p$ dari perairan Banten Selatan. Prosiding Seminar Biologi Nasional di Yogyakarta, Tanggal 16-17 September 2005. 9 pp.

Souza, TM., Abrantes, JL., De A Epifiano R. Leite Fontes, CF. and Frugulhetti, C. 2007. The alkaloid 4methylaaptamine isolated from the sponge Aaptos aaptos impairs herpes simplex virus type 1 penetration and immediate protein synthesis. Planta Med. 73(3): 200-205. 
